
RESEARCH AND DEVELOPMENT

\author{
http://journal.unnes.ac.id/sju/index.php/higeia
}

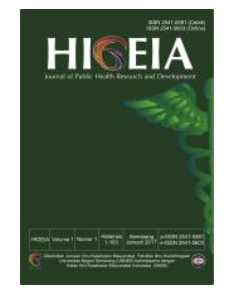

\title{
IMPLEMENTASI KEBIJAKAN PERMENKES NOMOR 67 TAHUN 2016 TENTANG PENANGGULANGAN TUBERKULOSIS
}

\author{
Naili Akrima Faradis ${ }^{\bowtie}$, Sofwan Indarjo \\ Administrasi Kebijakan Kesehatan, Jurusan Ilmu Kesehatan Masyarakat, \\ Fakultas Ilmu Keolahragaan, Universitas Negeri Semarang
}

\begin{abstract}
Info Artikel
Sejarah Artikel:

Diterima Februari 2018

Disetujui Maret 2018

Dipublikasikan April 2018

Keywords:

Implementation, Policy, Countermeasures,

Tuberculosis

Tuberculosis

Abstrak

Tuberkulosis merupakan penyakit menular yang masih menjadi masalah kesehatan masyarakat dan salah satu penyebab kematian, sehingga perlu dilaksanakan program penanggulangan TB secara berkesinambungan. Tujuan penelitian adalah menganalisis implementasi kebijakan tentang penanggulangan TB di Kota Tegal. Penelitian ini dilaksanakan pada bulan Oktober 2017. Jenis penelitian ini merupakan penelitian kualitatif dengan teknik pengambilan informan secara purposive sampling. Informan utama yaitu pengelola program $\mathrm{TB}$ di fasyankes dan petugas analis di fasyankes. Uji validitas dengan triangulasi sumber kepada pengelola program TB Dinkes Kota Tegal, kepala fasyankes dan paseien tuberkulosis. Hasil penelitian menunjukan bahwa pelaksanaan implementasi kebijakan belum berjalan secara maksimal. Dari empat variabel yang berpengaruh dalam pelaksanaan implementasi kebijakan yaitu kemampuan implementor kebijakan; sumber daya kebijakan; hubungan antar organisasi; dan kondisi lingkungan, masih terdapat dua variabel yang belum berjalan secara maksimal sehingga menghambat pelaksanaan implementasi ini. Dua hal tersebut adalah sumber daya kebijkan yang belum sepenuhnya terpenuhi, dan kurangnya dukungan masyarakat dalam penanggulangan TB.
\end{abstract}

\begin{abstract}
Tuberculosis was a contagious disease that was still a public health problem and one of the causes of death, so it needed to be implemented program of TB prevention on an ongoing basis. The purpose of this research was to analyze the implementation of policy on TB prevention in Tegal City. The research was conducted in October 2017. This type of research was a qualitative research with the technique of taking informants by purposive sampling. The main informants ware TB program managers in fasyankes and analyst officers in fasyankes. Test the validity of this study with source triangulation. The results showed that the implementation of policy implementation has not been run optimally. From those four variables that have an influence in the implementation of policy implementation: the ability of policy implementers; policy resources; organizational relationships; and environmental conditions, there ware two variables that has not been run optimally so that obstruct the implementation. Two of those were unfulfilled policy resources, and lack of community support for TB control.
\end{abstract}

E-mail: akrima.faradis@gmail.com 


\section{PENDAHULUAN}

Tuberkulosis (TB) merupakan salah satu penyakit menular tertinggi yang perlu diwaspadai dimasyarakat sampai saat ini. TB berdampak luas terhadap kualitas hidup dan ekonomi bahkan mengancam keselamatan jiwa manusia. Berdasarkan data WHO (World Health Organization) tahun 2015, pada tingkat global diperkirakan 10,4 juta kasus TB baru dan 3,5 juta (34\%) diantaranya berjenis kelamin perempuan dengan 1,4 juta kematian. Penyakit tuberkulosis paru menduduki peringkat ke sembilan dengan perkiraan kasus 1,37 juta/tahun. Dari seluruh kasus TB paru di dunia Negara India, Indonesia, China merupakan negara dengan penderita TB terbanyak yaitu berturut-turut $23 \%, 10 \%$ dan $10 \%$ dari seluruh penderita di dunia (WHO, 2015).

Menurut Hasil Survei Prevalensi TB Nasional 2016, Indonesia berada pada peringkat kedua negara dengan beban TB tertinggi didunia. Penemuan kasus TB penduduk Indonesia pada tahun 2015 yaitu sebesar 330.910 kasus, kasus ini mengalami peningkatan dibandingkan kasus TB yang ditemukan pada tahun 2014 yaitu 324.539 kasus. Prevalensi kasus TB di provinsi Jawa Tengah pada tahun 2015 yaitu sebesar 115,17 per 100.000 penduduk, kasus ini mengalami peningkatan dibandingkan kasus TB pada tahun 2014 yaitu sebesar 55,99 per 100.000 penduduk. Kota Tegal merupakan salah satu kabupaten/kota dengan angka kejadian TB paru yang menyumbang angka kejadian TB paru yang cukup tinggi. Jumlah kasus TB paru di kota Tegal pada tahun 2014 sebanyak 944 kasus (121 per 100.000 penduduk), mengalami peningkatan pada tahun 2015 yaitu sebesar 478,7 per 100.000 penduduk (Dinkes Provinsi Jateng, 2016).

Penyebab utama yang mempengaruhi peningkatan angka penderita tuberkulosis di Kota Tegal antara lain: a) kondisi sosial ekonomi yang menurun pada berbagai kelompok masyarakat, yaitu kurang terpenuhinya status gizi, b) kondisi lingkungan dalam dan luar rumah sangat mendukung terjadinya penyakit tuberculosis, c) perubahan demografi karena meningkatnya penduduk yaitu wilayah dengan kepadatan yang cukup tinggi, d) dampak pandemik HIV, yaitu faktor daya tahan tubuh seseorang akibat pengaruh aspek gizi dan infeksi lain sehingga mengakibatkan penurunan daya tahan tubuh seperti HIV. Kurang memadahinya tatalaksana dan belum optimalnya pelaksanaan program penanggulangan TB di kabupaten/ kota menjadi sorotan bagi pemerintah. Untuk menurunkan angka kesakitan dan angka kematian penyakit TB, Menteri Kesehatan telah mengeluarkan kebijakan Permenkes No. 67 tahun 2016 tentang penanggulangan TB. Sehingga dari kebijakan ini diharapkan dapat mencapai target SDG's pada tahun 2030 yang akan.

Berdasarkan hasil observasi di Dinas Kesehatan Kota Tegal dalam evaluasi program tahunan penanggulangan TB ditemukan bahwa indikator utama yang digunakan untuk menilai pencapaian strategi nasional penanggulangan TB masih ada beberapa indikator yang belum bisa mencapai target, diantaranya 1) indikator cakupan pengobatan semua kasus TB yang diobati (Case Detection Rate/ CDR) hanya $40,09 \%$ dari target $42 \%$ pada tahun $2016 ; 2$ ) angka keberhasilan pengobatan pasien TB semua kasus, hanya $75,8 \%$ dari target $90 \%$ pada tahun 2016; dan 3) angka keberhasilan pengobatan pasien TB resistan obat prosentase $0 \%$ dari $65 \%$. Hal ini membuktikan bahwa belum adanya pasien TB resisten obat yang sembuh. Disisi lain, hasil pencatatan dan pelaporan TB sensitif obat serta sistem pencatatan dan pelaporan TB resistan obat di Dinkes Kota Tegal, menunjukkan masih adanya fasyankes dalam kategori jelek dari hasil uji silang triwulan 1-3 tahun 2016. Hasil laporan absensi cros cek triwulan 4 tahun 2016 menunjukkan masih adanya keterlambatan dalam pengiriman laporan yaitu Puskesmas Margadana.

Berdasarkan hasil wawancara dengan pengelola program penanggulangan TB Dinas Kesehatan Kota Tegal pada tanggal 20 April 2017, diperoleh informasi bahwa kebijakan penanggulangan $\mathrm{TB}$ yang digunakan saat ini 
sudah sesuai dengan Permenkes No. 67 Tahun 2016. Meskipun beberapa target sudah tercapai akan tetapi masih ada kendala-kendala yang harus dihadapi dalam melaksanakan kebijakan penanggulangan TB yaitu masih belum tercapainya target dalam penurunan angka kesakitan dan angka kematian karena TB. Masih kurangnya komunikasi antara Pihak Dinas Kesehatan dengan pengelola program TB di Puskesmas, hal ini bisa dilihat dari belum adanya sosialisasi langsung dari Pihak Dinas Kesehatan Kota Tegal ke pelaksana di tingkat Puskesmas. Banyaknya pasien pengobatan yang berhenti di tengah jalan mempersulit dalam pelacakan pasien mangkir, hal ini dapat dilihat masih kurangnya kesadaran masyarakat dalam peningkatan kemandirian masyarakat dan tatalaksana penanganan TB. Cakupan pengobatan semua kasus TB dan angka keberhasilan pengobatan pasien TB di Dinas Kesehatan Kota Tegal masih dibawah target yang telah ditetapkan, sehingga belum maksimalnya pengendalian faktor risiko dalam penanggulangan TB.

Strategi penanggulangan TB dalam pencapaian eliminasi nasional TB meliputi: a) penguatan kepemimpinan program $\mathrm{TB}$ di kabupaten/kota, b) peningkatan akses layanan TB yang bermutu, c) pengendalian faktor resiko, d) peningkatan kemitraan $\mathrm{TB}$ melalui forum koordinasi $\mathrm{TB}$, e) peningkatkan kemandiria masyarakat dalam penanggulangan TB. Adapun kegiatan pada program penanggulangan $\mathrm{TB}$ dilaksanakan melalui upaya kesehatan masyarakat dan upaya kesehatan perorangan. Upaya penanggulangan TB dalam Permenkes No.67 tahun 2016 diselenggarakan melalui kegiatan, sebagai berikut: promosi kesehatan, surveilans $\mathrm{TB}$, pengendalian faktor resiko, penemuan dan penanggulangan kasus $\mathrm{TB}$, pemberian kekebalan, dan pemberian obat pencegahan.

Berdasarkan latar belakang diatas, maka tujuan penelitian ini untuk mengetahui bagaimana implementasi kebijakan penanggulangan $\mathrm{TB}$ di Kota Tegal yang dipandang oleh peneliti sebagai suatu aspek yang perlu untuk dikaji dan diteliti. Diadakan penelitian ini diharapkan bahwa hasil penelitian pada akhirnya dapat digunakan sebagai landasan kerja dalam menjalankan salah satu fungsi yaitu memberantas penyakit TB.

\section{METODE}

Penelitian ini difokuskan pada implementasi penanggulangan $\mathrm{TB}$ di fasilitas pelayanan kesehatan wilayah Kota Tegal antara lain kemampuan implementor kebijakan, sumber daya kebijakan, hubungan antar organisasi dan kondisi lingkungan suatu kebijakan. Implementasi merupakan tahap dimana suatu kebijakan dilaksanakan secara maksimal dan dapat mencapai tujuan kebijakan itu sendiri. Tahapan implementasi menjadi begitu penting karena suatu kebijakan tidak akan berarti apa-apa jika tidak dapat dilaksanakan dengan baik dan benar. Hal ini tentu juga dipengaruhi oleh beberapa variabel yang mendukung atau mempengaruhinya, untuk itulah perlu dilakukan penelitian tentang implementasi kebijakan penanggulangan TB di Wilayah kota Tegal.

Jenis dan rancangan penelitian menggunakan jenis penelitian deskriptif dengan pendekatan kualitatif. Jenis penelitian deskriptif kualitatif ini menggunakan rancangan penelitian studi kasus. Penelitian ini dilakukan pada bulan Oktober 2017 di fasilitas pelayanan kesehatan (Puskesmas dan Balai Paru) Kota Tegal.

Sumber data primer penelitian ini berasal dari informan penelitian. Penentuan informan dalam penelitian ini menggunakan teknik purposive sampling. Informan dalam penelitian ini dibagi dua kategori yaitu informan utama dan informan triangulasi. Informan utama yang menjadi narasumber dalam penelitian ini antara lain 6 orang pelaksana di fasyankes yang terdiri dari petugas pemegang program $\mathrm{TB}$ dan tenaga analis. Sedangkan informan triangulasi dalam penelitian ini antara lain pemegang program TB di Dinas Kesehatan Kota Tegal, kepala fasyankes di Kota Tegal, dan pasien TB. Sumber data sekunder penelitian ini terdiri dari literatur-literatur relevan, buku-buku, atau data yang terkait dengan topik penelitian. 
Dokumentasi, yaitu arsip-arsip serta laporan tertulis yang mendukung data penelitian meliputi data kasus TB Dinas Kesehatan Kota Tegal 2016, laporan triwulan penemuan dan pengobatan TB, laporan hasil evaluasi penurunan angka kesakitan dan kematian akibat TB di masyarakat tahun 2016.

Teknik pengambilan data yang digunakan dalam penelitian ini lebih banyak pada observasi berperan serta, wawancara mendalam, dan dokumentasi.Prosedur penelitian yang digunakan adalah dengan memberikan gambaran tentang keseluruhan perencanaan, pelaksanaan pengumpulan data, analisis data, penafsiran data, sampai penulisan laporan. Tahap penelitian ini terdiri dari tahap pralapangan, tahap pekerjaan lapangan, dan tahap analisis data. Pemeriksaan keabsahan data dalam penelitian ini menggunakan metode triangulasi. Teknik triangulasi yang dilakukan dalam penelitian ini adalah triangulasi sumber.

Teknik analisis data dalam penelitian ini terdiri dari tiga bagian, yaitu reduksi data sebagai proses pemilihan, pemusatan perhatian pada penyederhanaan, pengabstrakan dan transformasi data kasar yang muncul dari catatan-catatan tertulis di lapangan. Tahap selanjutnya adalah penyajian data, pengujian data kualitatif yang digunakan adalah dalam bentuk uraian singkat dan teks naratif. Tahap yang terakhir adalah penarikan kesimpulan/verifikasi, penarikan kesimpulan dengan membandingkan pertanyaan peneliti dengan hasil penelitian.

\section{HASIL DAN PEMBAHASAN}

Kemampuan implementor disini adalah sikap para pelaksana yang mendukung kebijakan yang telah ditetapkan. Keberhasilan suatu kebijakan dapat dipengaruhi oleh tingkat kompetensi dan keterampilan dari implementor kebijakan. Dalam penelitian ini keterampilan implementor sangat berpengaruh besar dalam penyampaian informasi kebijak, dimana informasi bisa tersalurkan keseluruh pelaksana program dengan adanya penguatan kepemimpinan program. Apabila implementor kebijakan memiliki disposisi yang baik, maka dia akan dapat menjalakan kebijakan dengan baik seperti apa yang diinginkan oleh pembuat kebijakan.

Berhubungan dengan kesedian dari para implementor untuk menyelesaikan kebijakan publik tersebut, kecakapan saja tidak mencukupi tanpa kesediaan dan komitmen untuk melaksanakan kebijakan. Menjaga konsistensi tujuan antara apa yang ditetapkan pengambilan kebijakan dan pelaksana kebijakan. Kunci keberhasilan program atau implementasi kebijakan adalah penguatan kepemimpinan program terhadap penerimaan dan dukungan atas kebijakan serta apa yang harus dilakukan, apa yang menjadi tujuan dan apa yang menjadi sasaran kebijakan yang harus diinformasikan kepada kelompok sasaran secara jelas.

Berdasarkan hasil wawancara dengan informan, maka dapat dikatakan sejauh ini penguatan kepemimpinan program dalam penyampaian informasi penanggulangan Tuberkulosis (TB) memperlukan upaya terpadu dan sistematis di berbagai aspek, baik melalui advokasi kebijakan; strategi komunikasi serta mobilisasi kekuatan elemen sosial kemsyarakatan. Komunikasi merupakan upaya untuk menciptakan opini atau lingkungan sosial yang mendorong masyarakat umum dan petugas kesehatan agar bersedia bersama-sama menanggulangi penularan TB. Komunikasi bertujuan untuk meningkatkan pengetahuan masyarakat tentang TB sehingga masyarakat mau dan mampu berkontribusi dalam upaya penanggulangan TB.

Menurut pemegang program $\mathrm{TB}$ di fasyankes strategi komunikasi dalam penyampaian informasi telah dijalankan dengan diadakannya penyuluhan kepada pasien dan masyarakat, baik penyuluhan secara langsung maupun penyuluhan secara tidak langsung. Penyuluhan TB secara langsung dilaksanankan dengan kader-kader maupun penyuluhan face to face dengan pasien, secara tidak langsung dengan pemutaran film di tempat pelayanan kesehatan. Hal ini sesui dengan pedoman yang telah ditetapkan standar keberhasilan komunikasi Permenkes penanggulangan TB. 
Hal ini sesuai dengan rencana kegiatan komunikasi dalam Permenkes penanggulangan TB 2016, yaitu strategi komunikasi yang dilakukan salah satunya adalah meningkatkan ketrampilan konseling dan komunikasi petugas maupun kader TB dilaksanakan pelatihan dan teknik komunikasi dalam penanggulangan TB. Metode penyuluhan langsung yaitu kunjungan rumah, pertemuan umum, pertemuan diskusi terarah dll, sedangkan metode penyuluhan tidak langsung dilakukan melalui media seperti pemutaran iklan layanan masyarakat di televisi, radio, youtube dan media sosial lainnya, tayangan film, pementasan wayang, dll.

Kader melakukan penyuluhan di masingmasing kelurahan setiap bulan. Penyuluhan dilaksanakan dengan beberapa cara misalnya dengan mengundang warga untuk berkumpul di satu tempat atau juga dilaksanakan pada saat ada kegiatan seperti pengajian, arisan, atau kegiatan penyuluhan kesehatan lainnya. Selain itu, upaya penyampaian informasi tentang $\mathrm{TB}$ dilakukan dengan komunikasi interpersonal, misalnya ketika bertemu dengan warga atau ketika melakukan door to door mencari suspek.

Komunikasi maupun ketrampilan penyampaian informasi dari implementor yang aktif merupakan langkah awal dalam penanggulangan $\mathrm{TB}$, karena dengan kegiatan komunikasi informasi tentang TB tersebar ke masyarakat dan membantu meningkatkan penemuan suspek, menghilangkan stigma tentang penyakit $\mathrm{TB}$ dan memutus rantai penularan TB di masyarkat.Upaya advokasi yang dilakukan kepada LSM, organisasi masyarakat dan tokoh masyarakat belum berjalan dengan maksimal. Dimana advokasi tersebut telah ada dalam program atau rencana yang ada di Dinas Kesehatan dan puskesmas.

Mobilitas sosial merupakan proses membangkitkan keinginan masyarakat, secara aktif meneguhkan konsesnsus dan komitmen sosial diantara pengambilan kebijakan untuk menanggulagi TB. Mobilitas sosial bararti melibatkan semua unsur masyarakat, sehingga memungkinkan masyarakat untuk melakukan kegiatan secara kolektif dengan menggumpulkan sumber daya dan membangun solidaritas untuk mengatasi masalah bersama. Pelaksanaan mobilitas sosisal pada masyarakat umum untuk ikut berpartisipasi dalam pengendalian TB, serta sebagian kader dimasing- masing masih belum berjalan dengan baik dikarenakan kurangnya upaya petugas kesehatan dalam melibatkan masyarakat umum. Promosi kesehatan yang telah dilakukan dalam penanggulangan TB ini untuk meningkatkan keterpaduan pelaksanaan program serta meningkatkan komitmen pengambilan kebijakan. Dinas kesehatan juga berupaya dalam melakukan sosialisasi agar terwujudnya kerjasama dalam penanggulangan TB paru, namun kerjasama lintas program hanya dilakukan sekali dalam setahun.

Mobilitas sosial dalam penelitian ini sejalan dengan penelitian Umiasih (2018), menyatakan bahwa peran serta kelompok masyarakat (Madupahat) tidak terlibat dalam perencanaan program pengendalian $\mathrm{TB}$, Madupahat melakukan upaya perencanaan kegiatan sosial yang berupa tali asih (kunjungan rumah anggota Madupahat), wisata sehat dan rapat bulanan. Namun Madupahat tidak berperan serta penuh dalam pengendalian TB. Informasi tersebut sudah tersalurkan dengan benar dan komunikasi mengenai adanya kebijakan ini sudah ditransmisikan dengan tepat serta terdapat banyak cara untuk mensosialisasikan kebijakan di fasilitas layanan kesehatan. Komitmen politis juga ditunjukan dengan adanya dukungan dari tokoh-tokoh masyarakat, tokoh agama, dan organisasi kemasyarakatan seperti aisiyah, fatayat NU untuk sinergisitas program.

Strategi komunikasi, advokasi, dan mobilisasi sosial merupakan hal yang saling berkaitan. Oleh karena itu ketiga strategi tersebut perlu dimaksimalkan pelaksanaannya. Penelitian Roddawwar (2008) di India menyimpulkan bahwa strategi AKMS (Advokasi, komunikasi, dan mobilitas sosial) meningkatkan deteksi kasus secara substansial dan membentuk mekanisme sistem rujukan yang kuat. kombinasi advokasi, komunikasi dan mobilisasi sosial adalah pendekatan yang 
menjanjikan untuk meningkatkan deteksi kasus TB.

Sesuai dengan penelitian Kamineni (2011) di Odisha, India menunjukan bahwa kombinasi faktor termasuk keterlibatan LSM (Lembaga Swadaya Masyarakat), Interface (yang menghubungkan pemerintah dengan LSM, NGO, dan organisasi lainnya yang terlibat), ditambah dengan pelatihan peningkatan dan keterlibatan tenaga kesehatan garis depan dan kelompok masyarakat, dan penyebaran sumber daya berbasis masyarakat, memberikan konstribusi untuk meningkatkan kesadaran dan pengetahuan tentang TB di kabupaten yang ditargetkan. Kegiatan proyek juga berkontribusi terhadap peningkatan kesadaran petugas kesehatan dan masyarakat untuk meningkatkan agenda TB, dan meningkatkan keaksaraan TB dan kepatuhan terhadap pengobatan. Keterlibatan pasien yang diobati dengan baik juga membantu mengurangi stigma dan diskriminasi masyarakat.

Berdasarkan hasil penelitian mengenai koordinasi kebijakan oleh pelaksana kebijakan melalui koordinasi antar instansi dan kerjasama lintas sektor dan lintas program. Kerjasama lintas sektor dilakukan dengan instansi, misalnya kerjasama dengan Dinas Kesehatan Kota Tegal dan BP4 sebagai rujukan pemeriksaan dahak, koordinasi jejaring penemuan kasus, koordinasi mutu laboratorium. Koordinasi ataupun kerjasama yang dibangun antara pelaksana dengan instansi lain untuk memperoleh dukungan serta informasi dari implementor. Dalam koordinasi untuk memperoleh informasi secara maksimal ada tiga prinsip yaitu kesetaraan, keterbukaan, dan saling menguntungkan antara pemangku kebijakan dengan yang lain.

Hasil penelitian pada wawancara ini mengatakan bahwa sudah terlaksanakannya koordinasi satu sama lain dalam penanggulangn TB, Dinas Kesehatan telah menjalankan koordinasi kebijakan dengan pihak fasilitas layanan kesehatan secara rutin. Bentuk koordinasi yang dijalankan yaitu koordinasi penjaringan suspek TB antara pihak BP4 dengan puskesmas dengan melibatkan pihak
Dinas Kesehatan, serta koordianasi jejaring laboratorium dengan pemeriksaan cross check di laboratorium fasyankes dan memerikan feedback sebagai hasil koordinasinya. Tidak hanya koordinasi saja dalam peningkatkan komunikasi antar fasyankes, Dinas Kesehatan juga melaksanakan supervisi yang telah dilaksanakan di setiap fasyankes di Kota Tegal sesuai dengan jadwal untuk memperkuat pelaksanaan kebijakan penanggulangan TB.

Selain dengan instansi pemerintah koordinasi ini juga dilakukan dengan instansiinstansi swasta yang ikut dalam memberikan dukungan pelaksanaan kebijakan penanggulangan TB. Sehingga dalam pencapaian tujuaan serta sasaran ini bisa berhasil dalam pelaksaan kebijakn membutuhkan pemangku kebijakan yang didalamnya ada organisasi kemasyarakataan yang mendukungnya. Hal ini sesuai dengan kegiatan memperkuat koordinasi dalam Permenkes penanggulangan TB 2016, yaitu penyelenggaraan penanggulangan $\mathrm{TB}$ perlu didukungan dengan upaya mengembangkan dan memperkuat mekanisme koordinasi, serta kemitraan antar pegelola program TB dengan instasi pemerintah lintas sektor dan lintas program, para pemangku kepentingan, asuransi kesehatan maupun dengan organisasi kemasyarakatan.

Hasil penelitian Budi (2012), menyatakan menunjukkan adanya kontribusi pengetahuan tentang koordinasi dan jenis koordinasi terhadap komunikasi dan supervisi. Terdapat kontribusi peran pengawasan terhadap komunikasi, supervisi dan prosedur kerja. Terdapat kontribusi mekanisme koordinasi kontribusi (pengawasan,komunikasi dan prosedur kerja) terhadap cakupan penemuan suspek TB.

Kualitas sumber daya manusia tidak hanya ditentukan oleh keahlian tetapi juga diiringi dengan sikap mental terkendali dan terpuji dalam mencapai tujuan kebijakan. Salah satu faktor keberhasilan kebijakan yaitu tersedianya sumber daya manusia yang cukup, baik dari segi kuantitas maupun kualitas. Sumber daya manusia merupakan pelaku aktif 
yang akan melakukan aktivitas sebagai pelaksana kebijakan.

Berdasarkan hasil penelitian menunjukan sebagian besar informan di fasilitas pelayanan tingkat pertama (FKTP) menyatakan SDM yang tersedia mencukupi dari segi jumlah yaitu 1 dokter, 1 petugas TB, dan 1 tenaga analis. Petugas TB mempunyai tugas antara lain melakukan penemuan kasus, penjaringan ke desa, membuat pencatatan dan pelaporan yang di serahkan ke dinas. Sementara dokter bertugas dalam mendiagnosa penderita TB. Petugas TB juga ikut dalam puskesmas keliling serta di beberapa fasyanke petugas TB merangkap tugas di puskesmas pembantu, sehingga tidak ada petugas lain yang berada di puskesmas untuk menangani penderita.

Hal ini sudah sesuai dengan standar minimal ketenagaan di FKTP dalam Permenkes penaggulangan TB 2016, yang menyatakan bahwa kebutuhan minimal tenaga pelaksana terlatih terdiri dari 1 dokter, 1 perawat/petugas TB, dan 1 tenaga laboratorium. Namun, ketenagaan di BP4 Kota Tegal belum sesuai dengan standar minimal ketenagaan BKPM dalam Permenkes penanggulangan TB. Dimana dijelaskan bahwa ketenagaan minimal terdiri 2 dokter (dokter umum, SpP/SpPD, SpRad), 3 perawat/petugas TB, 1 tenaga laboratorium, dan 1 tenaga farmasi.

Ketenagaan petugas TB di BP4 Kota Tegal hanya ada satu pengelola saja, sehingga dalam pelaksanaan program petugas pemegang program TB membutuhkan tenaga bantu untuk menyelesaikan pekerjaannya agar sesuai dengan waktu yang ditetapkan. Jumlah petugas yang sedikit dan tugas yang banyak menjadikan kendala melakukan penemuan kasus secara aktif dan pelaksanaan kebijakan secara maksimal. Tenaga kesehatan yang terlibat dalam penanggulangan TB di Kota Tegal bukan hanya tanggung jawab petugas TB di fasyankes saja melainkan adanya tenaga kesehatan lain yang ikut terlibat. Petugas TB paru tidak akan mampu mengatasi permasalahan TB tanpa adanya kerjasama dengan tenaga kesehatan lainnya. Di setiap fasyankes melakukan kerjasama dengan Dinas Kesehatan Kota Tegal dan Fasilitas pelayanan kesehatan tingikat lanjut.

Dinas Kesehatan Kota Tegal berperan sebagai wasor yang setiap 1 bulan meninjau ke puskesmas maupun balai paru untuk monitoring dan evaluasi. Monitoring dan evaluasi yang dilakukan seiring dengan pelaksanan supervisi ke puskesmas maupun balai paru. Pada saat supervisi juga dilakukan pencatatan dan pelaporan penderita TB, keterlambatan pelaporan dari puskesmas yang tidak tepat waktu menjadi hambatan dalam pelaksanaan kebijakan sehingga dinas kesehatan membuat aturan dalam pengumpulan laporan setiap bulannya dengan memberikan batasan waktu yang ditentukan.

Dari informasi yang didapatkan, sebagian besar informan mengatakan kurangnya pelatihan terhadap tenaga analis disetiap fasyankes, hal ini dikarenakan tidak adanya pelatihan berjenjang sehingga tenaga kurang update dengan ketentuan-ketentuan baru. Sementara mutasi tenaga analis juga berpengaruh terhadap sumber daya yang kurang berkompeten. Pelatihan merupakan salah satu upaya penting pengetahuan, sikap dan ketrampilan petugas dalam rangka meningkatkan mutu dan kinerja petugas. Pelatihan berjenjang dan berkelanjutan merupakan bagian dari pengembangan sumber daya manusia. Apabila semua petugas TB di puskesmas maupun balai paru telah mingikuti pelatihan dan menerapan dalam pelayanan kesehatan maka diharapkan angka penurunan kesakitan karena TB sebesar 30\% dan angka kematian karena TB sebesar $40 \%$.

Hasil penelitian mengenai pelatihan petugas TB yang masih kurang maksimal sejalan dengan penelian Mansur (2015) yang menyatakan bahwa petugas TB paru di Puskesmas Desa Lalang telah mendapatkan pelatihan mengenai TB paru. Pelatihan yang di dapat petugas TB paru yaitu mengenai pencatatan dan pelaporan, pelatihan dalam hal fiksasis slide, penjaringan terhadap suspek TB paru, dan pemeriksaan dahak secara mikroskopis. Namun pelatihan yang di dapat oleh petugas TB paru hanya sekali saja. Serta 
menurut laporan dari Zignol (2016) mengatakan bahwa diperlukan tenaga terlatih untuk mendiagnosa pasien TB RO dengan benar dan memberikan terapi yang tepat.

Selain sumber daya manusia adanya ketersediaan dana kebijakan menjadi faktor pendukung dalam terlaksananya sebuah kebijakan termasuk juga kebijakan penanggulangan TB. Ketersediaan dana yang cukup akan menunjang proses kebijkan agar efektif dan efisien, sehingga suatu kebijakan akan menjadi terhambat jika dana yang ada tidak memadai. Dana dalam pelaksanaan penanggulangan TB di fasyankes berasal dari Dinas Kesehatan. Dinas kesehatan memperoleh dana dari APBN, APBD, BOK serta dana Global Fund berupa hibah (bantuan) secara nasional. Failitas pelayanan kesehatan dalam pelacakan kasus TB yang mangkir maupun pembiayaan operasinal petugas dalam penanggulangan $\mathrm{TB}$ menggunakan dana dari anggaran bantuan oprasional kesehatan (BOK).

Anggaran khusus untuk kegiatan penanggulangan TB di Kota Tegal ini belum ada, hanya ada dana untuk oprasional saja yang diterima. Biaya pelatihan yang diberikan di setiap daerah sangatlah minim serta akan diadakannya pengurangan usulan pengajuan pelatihan dari pusat, sehingga Dinas Kesehatan berupaya untuk meningkatkan pembiayaan penanggulangan $\mathrm{TB}$ dengan melaksanakan RAD agar bisa terpenuhinya pembiayaan pelatihan untuk pelaksana. Penelitian ini sejalan dengan penelitian Budiman (2012) yang mengatakan bahwa pelaksanaan pengendalian tuberkulosis dari aspek ketersediaan dana sudah memadai, sumber dana terbesar berasal dari Global Fund. Kontribusi Global Fund sangat signifikan terhadap berjalannya kegiatan pengendalian TB di Kota Padang, sedangkan sumber dana dari pemerintah kota sangat minim. Hal ini dikarenakan pemerintah daerah Kota Padang menganggap dana untuk kegiatan program sudah cukup besar dalam upaya pengendalian tuberkulosis di Kota Padang.

Pelaksanaan penanggulangan TB khususnya penemuan kasus dan pemerikasaan dahak tidaklah terlepas dari tersedianya sarana dan prasarana untuk mendukung kebeprogram tersebut. Sarana adalah segala sesuatu yang digunakan sebagai alat untuk mencapai tujuan tertentu, sedangkan prasarana merupakan segala sesuatu yang digunakan sebagai penunjang dalam melaksanakan suatu kegiatan. Pelaksanaan kebijakan penanggulangan TB di fasilitas pelayanan kesehatan diperlukan saran dan prasaran seperti ruang kerja khusus program TB, ketersediaaan laboratorium yang mampu melakukan pemeriksaaan mikroskop dahak, terseianya alat dan bahan laboratorium sesuai standar, serta adanya pemeriksaan TCM (Tes Cepat Molekuler) untu penegakan diagnosis di FKTL (Fasilitas Pelayanan Kesehatan Tingkat Lanjut).

Berdasarkan penelitian yang telah dilakukan bahwa di fasilitas pelayanan kesehatan Kota Tegal telah memiliki sarana sesuai dengan standar permenkes penanggulangan $\mathrm{TB}$, seperti tersedianya laboratorium mandiri di setiap fasyankes untuk melaksanakan penegakan diagnosis dengan uji dahak menggunakan mikroskop. Selain itu, pengadaan alat dan bahan pemeriksaan laboratorium sudah terpenuhi Dinas Kesehatan, serta diadakan kalibrasi dan uji fungsi secara rutin untuk pemeliharaan alat laboratorium. Meskipun sarana prasarana sudah tercukupi akan tetapi di puskesmas Kota Tegal tidak terdapat ruang khusus TB dalam pemeriksaan maupun penanganan penderita $\mathrm{TB}$.

Ketersediaan obat dan perbekalan kesehatan (logistik TB) merupakan bagian terpenting dalam keberhasilan Program Penanggulangan TB. Pengelolaan ketersediaan logistik TB merupakan suatu rangkaian kegiatan untuk menjamin agar logistik Program Penanggulangan TB tersedia di setiap layanan pada saat dibutuhkan dengan jumlah yang cukup dan kualitas yang baik. Kebutuhan logistik dalam Permenkes penanggulangan TB 2016 terdiri dari Logistik Obat Anti Tuberkulosis (OAT) dan logistik Non OAT. Logistik Obat Anti Tuberkulosis (OAT) adalah semua jenis OAT yang digunakan untuk mengobati pasien TB, baik TB Sensitif maupun TB Resistan Obat (TB-RO). Logistik Non OAT 
adalah semua jenis bahan dan alat kesehatan selain OAT yang digunakan untuk mendukung tatalaksana pasien TB.

Berdasarkan hasil wawancara dengan pelaksana penanggulangan $\mathrm{TB}$ di fasyankes bahwa persedian obat menjadi salah satu faktor terpenting dalam program penanggulangan TB. Persediaan obat disetiap fasyankes sudah tercukupi oleh Dinas Kesehatan, setiap permintaan obat ke dinas selalu tersedia dengan surat pengajuan permintaan. Selanjutnya, Dinas Kesehatan juga membuat permintaan obat ke instansi gudang farmasi di Kota Tegal. Dalam pengajuan permintaan obat ke dinas selalu aktif dan sigap untuk ketersediaan obat di setiap fasyankes untuk menanggulangi agar tidak terjadi kekosongan logistik obat di fasyankes dalam penanggulangan TB. Penelitian ini sejalan dengan penelitian Mansur (2015) mengatakan bahwa Puskesmas Desa Lalang sudah memiliki persediaan obat yang cukup, Puskesmas mengambil persediaan obat ke Puskesmas Rujukan Mikroskopis (PRM) Helvetia. OAT yang diberikan melalui Instalasi Gudang Farmasi Kota Medan kepada Puskesmas Helvetia sebagai PRM dengan membuat permintaan obat ke Dinas Kesehatan dan dilanjutkan membuat permintaan ke instalasi gudang farmasi, kemudian diserahkan ke puskesmas satelit yang bekerjasama dengan PRM. Walaupun obat di puskesmas habis, maka petugas TB akan mencari obat TB paru ke puskesmas lain.

Tersedianya bahan-bahan perbekalan kesehatan TB (logistik Non OAT) habis pakai maupun bahan tidah habis pakai sudah terpenuhi di setiap fasyankes. Namun masih ada beberapa kebutuhan barang habis pakai belum sepenuhnya terpenuhi seperti formulir pencatatan dan pelaporan di fasyankes masih mencetak sendiri sehingga membutuhkan pendanaan untuk mencetak formulir. Hal ini sebagian besar logistik sudah sesuai dengan standar dalam Permenkes penaggulangan TB 2016, yang menyatakan bahwa kebutuhan Logistik Non OAT habis pakai terdiri dari tersedianya bahan-bahan laboratorium TB, seperti pot dahak, reagen, kaca sediaan, tisu,sarung tangan, kertas saring, kertas lensa serta tersedianya semua formulir pencatatan dan pelapora. Logistik Non OAT tidak habis pakai terdiri dari alat-alat laboratorium TB, seperti tes cepat molekuler, mikroskop, lampu spiritus/Bunsen, rak slide, box slide, rak penyimpan OAT serta tersedianya buku pedoman, buku panduan, buku petunjuk teknis, leaflet, poster dll.

Lengkapnya pencatatan dan pelaporan di puskesmas maupun di balai paru menggunakan catatan tertulis maupun secara sistem. Formulir yang tersedia di puskesmas maupun di balai paru dicatat sesuai jumlah pasien yang berobat, dengan format laporan yang ada, selanjutnya petugas TB harus sudah selesai mengisi laporannya setiap bulan yang kemudian dilaporkan ke Dinas Kesehatan sebelum tanggal 5 untuk diperiksa ulang oleh petugas dinas. Serta didukung oleh sistem pelaporan tuberkulosis yang memakai sistem elektronik dan dilaporkan secara online bernama SITT (Sistem Informasi Terpadu Tuberkulosis), sehingga dapat meminimalisir terjadinya laporan hilang, pencatatan ganda serta lebih efisien dan efektif sehingga lebih cepat pula mendapat feedback dari dinas kesehatan. Pencatatan dan pelaporan yang lengkap dan baik tentunya akan berhubungan dengan kualitas petugas TB yang baik. Namun, disisi lain masih banyak petugas yang terlambat dalam laporan kedinas kesehatan dikarenakan malasnya petugas TB untuk memasukkan data pasien ke sistem. Hasil penelitin ini sejalan dengan penelitian Noveyani (2013), menyatakan bahwa pencatatan dan pelaporan di puskesmas Tanah Kalikedinding cukup lengkap karena telah menggunakan sistem pelaporan tuberkulosis dengan sistem elektronik dan dilaporkan secara online bernama SITT (Sistem Informasi Terpadu Tuberkulosis)

Komitmen pemerintah dimana melibatkan para pemegang kebijikan dan kerjasama lintas sektoral artinya bersifat menyeluruh, bukan hanya departemen kesehatan saja tetapi berbagai instansi pemerintah terkait, baik hubungannya dengan pendanaan, pelaksanaan di daerah serta hal 
terkait lainnya. Hubungan antar organisasi untuk memberikan prioritas dalam penanggulangan tuberculosis merupakan kunci utama keberhasilan kebijakan ini. Dalam menatalaksana penanggulangan $\mathrm{TB}$ secara komprehensif diperlukan kerja sama terintegrasi antara semua pemberi pelayanan baik pemerintah maupun swasta dalam bentuk PPM (Publik Private Mix). Dengan melibatkan para pemegang kebijakan dan kerjasama lintas sektoral tersebut, diharap dapat mencapai tujuan serta target nasional yaitu penurunan angka kesakitan dan angka kematian karena TB.

Berdasarkan hasil penelitian di fasyankes Kota Tegal dalam peningkatan kemitraan penanggulangan TB telah dijalankan melalui hubungan kerjasama antara pihak pemerintah dengan pemerintah, maupun swasta dengan swasta. Hubungan kerjasama/ bauran pemerintah dengan pemerintah dalam upaya penanggulangan TB melibatkan banyak institusi pemerintah baik lintas program maupun lintas sektor. Kerjasama yang melibatkan instansi lintas program dalam pelaksanaanya penanggulangan TB seperti koramil, KUA, BAPPEDA, UPT Pendidikan, dan Dinas Sosial. Perluasan pelaksanaan program tersebut tidak lepas dari adanya komitmen dari forum aisiyah. Aisiyah merupakan suatu forum yang bergerak dalam penanggulangan TB dengan melibatkan seluruh pihak di seluruh masyrakat baik swasta dan pemerintah agar dapat meningkatkan kesadaran, kemauan, dan kemampuan hidup sehat. Diharapkan dapat mempercepat upaya penanggulangan TB dengan melakukan kemitraan dan kerjasama lintas sektor dan lintas program.

Upaya penanggulangan TB melibatkan banyak instansi agar memperluas pelaksanaan penanggulangan $\mathrm{TB}$, sehingga dibutuhkan keikutsertaan berbagai sektor yang terkait dalam menanggulangi masalah TB. Penanggulangan TB dilaksanakan oleh instansi kesehatan pusat, provinsi, kabupaten/kota seperti dinas kesehatan provinsi, dinas kesehatan kabupaten/kota. Kerjasama lintas sektor juga diselenggarakan dengan kecamatan dan desa/kelurahan agar mendukung pelaksanaan program. Peran serta masyarakat yaitu melakukan penyampaian informasi, pemberian batuan saran, pengembangan informasi, dan memberikan pemikiran dan pertimbangan terhadap kebijakan.

Berdasarkan hasil penelitian di fasyankes Kota Tegal dalam penanggulangan TB telah melakukan kerjasama lintas sektor dan lintas program. Kerjasama lintas sektor dilakukan dengan instansi, misalnya kerjasama dengan Dinas Kesehatan Kota Tegal, Rumah Sakit, Puskesmas, serta Balai Paru. Sementara kerjasma lintas program dilakukan dengan pihak-pihak kelurahan maupun desa seperti camat, lurah, koramil, polsek, UPT pendidikan, tokoh masyarakat RTMP, KUA, Dinas Sosial, serta tokoh agama untuk mendapatkan dukungan serta support baik dalam penanggulangan TB.Kerjasama lintas sektoral ini tidak hanya dilakukan oleh pihak fasilitas pelayanan kesehatan saja. Dinas kesehatan juga berupaya dalam melakukan sosialisasi agar terwujudnya kerjasama dalam penanggulangan $\mathrm{TB}$, namun kerjasama lintas sektor ini dirasa kurang berjalan lancar. Hal ini dikarenakan masih banyak instansi-instansi yang belum berperan dalam penanggulangan $\mathrm{TB}$ hanya BAPPEDA yang sudah berperan nyata untuk penanggulangan TB. Penelitian ini tidak sejalan dengan penelitian Tondong (2014) menyatakan bahwa faktor faktor yang menghambat implementasi PPM pengendalian TB salah satunya adalah kurangnya komitmen pemerintah maupun mitra dalam implementasi PPM pengendalian TB, serta kurangnya komunikasi dan koordinasi antar jejaring PPM dalam menjaga keteraturan dan keberlangsungan penanggulangan TB.

Lingkungan tempat kebijakan dioperasikan sangat mempengaruhi keberhasilan implementasi suatu kebijakan. Lingkungan ini mencakup lingkungan sosial, politik, ekonomi, hankam dan fisik atau gegrafis. kebijakan lingkungan merupakan setiap tindakan yang dilakukan atau tindakan tidak dilakukan pemerintah untuk mencapai tujuan dan sasaran tertentu dibidang lingkungan serta bagaimana cara dan dengan sarana apa 
pengelolaan lingkungan dilaksanakan untuk mencapai tujuan dan sasaran tersebut. Keberhasilan sebuah kebijakan juga ditentukan oleh dukungan dan partisipasi dari masyarakat, sehingga dengan suka rela dan kesadaran melaksanakan suatu kebijakan yang ditetapkan oleh pemerintah. Menurut Helper (2010) menyatakan bahwa peningkatan kasus TB dipengaruhi oleh daya tahan tubuh, status gizi dan kebersihan diri individu dan kepadatan hunian lingkungan tempat tinggal. Keluarga yang mempunyai pendapatan yang lebih tinggi akan lebih mampu untuk menjaga kebersihan lingkungan rumah tangganya, menyediakan air minum yang baik, membeli makanan yang jumlah dan kualitasnya memadai bagi keluarga mereka, serta mampu membiayai pemeliharaan kesehatan yang mereka perlukan.

Berdasarkan hasil penelitian menunjukan bahwa kebijakan penanggulangan $\mathrm{TB}$ ini memiliki respon positif dari pihak pemerintah maupun masyarakat. Namun masih ada sekelompok masyarakat dalam pendukung pelaksanaan kebijakan penanggulangan $\mathrm{TB}$ masih rendah, dikarenakan kurangnya kesadaran akan berobat dan kesembuhaan diri. Banyak pasien yang mangkir atau berhenti ditengah jalan dalam berobat. Disamping itu dukungan dari kader dan forum masyarakat dalam pemaksimalan penemuan TB secara dini belum berjalan secara maksimal. Penemuan secara dini pendirita TB hanya dilakukan secara pasif di fasyankes, artinya penjaringan penderita dilaksanakan pada mereka yang datang berkunjung ke pelayanan kesehatan.

Dukungan sosial yang kuat pada pasien terutama dari pihak keluarga sangat membantu proses penyembuhan penyakit $\mathrm{TB}$ paru, misalnya terkait dengan kepatuhan menelan obat yang berlangsung selama 6 bulan. Pengaruh tidak langsung dukungan sosial adalah menurunkan stres yang dihadapi pasien yang selanjutnya mempengaruhi kesehatan jiwa seseorang. Hasil temuan Rintiswati (2009), bahwa pasien tidak merasa tersingkir dalam lingkungan keluarga atau masyarakat karena baik pasangan, kerabat dan teman-teman mendukung atau tidak menunjukkan perubahan perilaku ketika diketahui pasien menderita TB.

Penyuluhan kesehatan yang merupakan bagian promosi kesehatan merupakan rangkaian kegiatan yang mendukung pelaksanaan kebijakan yang berlandaskan prinsip-prinsip belajar untuk mencapai suatu keadaan dimana individu, kelompok, atau masyarakat secara keselurhan dapat hidup sehat dengan cara memelihar, melindungi dan meningkatan kesehatan. Hasil penelitian yang dilakukan menyatakan bahwa penyuluhan dilakukan di luar gedung dan dalam gedung. Penyuluhan diluar gedung dilaksanakan bersama dengan kader kesehatan, sehingga puskesmas tidak memiliki jadwal yang tetap dalam penyuluhan. Penyuluhan didalam gedung dilaksanakan pada saat pasien mengantri untuk diperiksa selalu dilakukan pada saat pemeriksaan dan pemberian obat kepada penderita, dengan memberikan pesan-pesan seperti memberikan semangat untuk tetap berobat teratur, makan tambahan dengan mengingatkan bahaya dari TB itu sendiri. Penyuluhan TB ini perlu dilakukan karena masalah TB banyak berkaitan dengan masalah pengetahuan dan perilaku masyarakat. Tujuan penyuluhan adalah untuk meningkatkan kesadaran, kemauan dan peran serta masyarakat dalam penanggulangan TB. Penyuluhan ditujukan kepada suspek, penderita dan keluarganya, supaya penderita menjalani pengobatan secara teratur hingga sembuh.

Penemuan penderita TB merupakan langkah pertama dalam kegiatan program penanggulangan TB. Dengan memaksimalkan penemuan TB secara dini akan dapat menurunkan kesakitan dan kematian akibat TB, serta penemuan TB di masyarakat dan sekaligus merupakan kegiatan pencegahan penularan TB yang paling efektif di masyarakat. Berdasarkan hasil wawancara penemuan secara dini pendirita TB di fasyankes dilakukan secara pasif, artinya penjaringan penderita dilaksanakan pada mereka yang datang berkunjung ke pelayanan kesehatan. Dengan kata lain, puskesmas melakukan penemuan kasus secara pasif, namun didukung juga 
dengan kegiatan penyuluhan secara aktif oleh petugas.

Penemuan kasus dengan cara penjaringan penderita TB paru ke desa pernah dilakukan, sementara penemuan kasus dengan mengunjungi rumah penderita $\mathrm{TB}$ paru tidak pernah dilakukan. Hal ini dikarenakan banyaknya pekerjaan petugas TB di fasyankes. Petugas TB paru mengatakan bahwa jadwal penjaringan dilaksanakan bersamaan dengan jadwal puskesmas keliling dan penjaringan tersebut dilakukan hanya sekali sebulan. Jadwal puskesmas keliling bersamaan juga dengan jadwal puskesmas lainnya untuk turun ke lapangan. Penemuan kasus secara aktif juga sangat diperlukan untuk mencegah penularan TB paru, misalnya dilakukan penjaringan kasus di sekitar wilayah tempat tinggal penderita $\mathrm{TB}$ paru. Hal ini perlu dilakukan mengingat penularan penyakit $\mathrm{TB}$ paru sangat cepat, terutama di lingkungan kumuh dan terdapat padat penduduk, namun hal ini belum pernah dilakukan karena petugas TB mempunyai banyak tugas dan terhambat dengan jumlah petugas yang sedikit. Penemuan secara pasif akan lebih efektif jika didukung oleh penyuluhan secara aktif, baik oleh petugas kesehatan maupun masyarakat, untuk meningkatkan cakupan penemuan penderita. Cara ini dikenal dengan pasive promotive case finding penemuan penderita secara pasif dengan promosi yang.

Berdasarkan hasil penelitian yang telah dilakukan, diketahui bahwa penyuluhan sudah diberikan, baik kepada penderita TB paru, keluarga TB paru, maupun masyarakat. Penyuluhan kepada masyarakat diberikan pada saat puskesmas keliling, masyarakat dikumpulkan kemudian diberikan penyuluhan. Penyuluhan tersebut dilakukan hanya pada masyarakat yang datang ke puskesmas keliling, sehingga tidak semua masyarakat mendapatkan penyuluhan. Hal ini dibenarkan oleh informan penderita dan PMO bahwa tidak pernah dilakukan penyuluhan. Pada saat melakukan penyuluhan, petugas TB paru bekerja sama dengan bagian promosi kesehatan (promkes) di fasilitas pelayanan kesehatan Kota Tegal.
Menurut Permenkes dalam penanggulangan TB 2016 bahwa salah satu tujuan jangka pendek program penanggulangan TB paru adalah tercapainya cakupan penemuan penderita baru TB secara bertahap hingga mencapai $70 \%$ dari semua penderita TB yang diperkirakan ada. Berdasarkan hasil penelitian diketahui bahwa target dalam penemuan kasus di wilayah kerja Dinas Kesehatan Kota Tegal belum memenuhi target. Hal ini dikarenakan kurangnya kesadaran dan pengetahuan masyarakat terhadap penyakit TB. Masih kurangnya pengetahuan di sebagian masyarakat mengenai TB menjadi kendala dalam program penanggulangan TB khususnya dalam penemuan kasus di fasilitas pelayanan kesehatan. Sebagian masyarakat beranggapan bahwa penyakit TB paru adalah penyakit kutukan, penyakit akibat guna-guna, dan aib. Minimnya pengetahuan akan penyakit TB paru menyebabkan penderita kurang aktif dalam memperoleh kesembuhan dan masih mengakibatkan penularan kepada orang lain.

Petugas TB paru sudah menyarankan kepada penderita dan keluarga penderita, jika terdapat gejala umum penyakit TB sebaiknya langsung melakukan pemeriksaan dahak. Petugas TB paru juga sudah berupaya memberi informasi mengenai penyakit TB paru, namun masih ada sebagian masyarakat yang tidak peduli. Hal ini sejalan dengan hasil wawancara yaitu masih ada penderita TB paru yang tidak mau mengantarkan kembali pot dahaknya ke puskesmas, meskipun petugas TB paru sudah menganjurkannya. Bagi sebagian penderita $\mathrm{TB}$ paru beranggapan bahwa penyakit $\mathrm{TB}$ paru merupakan aib bagi mereka dan mereka malu untuk memeriksakan kesehatannya.

\section{PENUTUP}

Berdasarkan hasil penelitian dan pembahasan dapat disimpulkan bahwa kemampuan implementor kebijakan dalam penyampaian informasi penanggulang $\mathrm{TB}$ dilaksanakan dengan penyuluhan kepada pasien maupun masyarakat. Serta Koordinasi dengan Dinas Kesehatan dengan memberikan 
pembinaan maupun supervisi di fasyankes. Hubungan kerjasama antar organisasi penanggulangan TB lintas program maupun listas sektor sudah berjalan sesuai dengan peraturan penanggulangan TB. Namun ketersediaan sumber daya kebijakan di fasyankes belum memenuhi kriteria yang ditetapkan oleh Permenkes. Dukungan masyarakat yang masih rendah masih terdapat hambatan yaitu masyarakat tidak kooperatif Penemuan kasus TB paru kebanyakan hanya menunggu sehingga tidak pernah dilakukan penjaringan suspek secara aktif.

Saran untuk penelitian selanjutnya yaitu dapat melakukan penelitian sejenis di tempat lain mengenai pelaksanaan penanggulangan tuberkulosis, dapat menggali informasi lebih dalam dengan menambahkan indikatorindikator lain yang belum diteliti dalam penelitian penanggulangan TB.

\section{DAFTAR PUSTAKA}

Budi, I., Damayanti, N., \& Wulandari, R. 2012. Kontribusi Koordinasi Terhadap Penemuan Suspek Tuberkulosis Paru di Kabupaten Madiun. Jurnal Manajemen Pelayanan Kesehatan, 15(1): 7-11

Budiman, H. 2012. Analisis Pelaksanaan Advokasi, Komunikasi dan Mobilisasi Sosial dalam Pengendalian Tuberkulosis di Dinas Kesehatan Kota Padang. Jurnal Kesehatan Masyarakat Andalas, 6(2): 95-103

Dinkes Provinsi Jateng. 2016. Provinsi Jawa Tengah Tahun 2015. Semarang: Dinkes Provinsi Jateng

Helper, S.P., 2010. Faktor-Faktor yang Mempengaruhi Kejadian TB Paru dan Upaya Penanggulangan. Jurnal Ekologi Kesehatan, 9(4): $1340-1346$

Kamineni, V.V., Turk, T., Wilson, N., Satyanarayana, S., \& Chauhan, L. 2011. A rapid Assessment and Response Approach to Review and Enhance Advocacy,
Communication and Social Mobilisation for Tuberculosis Control. BMC Publik Health in Odisha state, 10(11): 463-475

Mansur, M., Khadijah, S., \& Rusmalawaty. 2015. Analisis Penatalaksanaan Program Penanggulangan Tuberkulosis Paru dengan Strategi DOTS di Puskesmas Desa Lalang Kecamatan Medan Suggal Tahun 2015. Jurnal Lingkungan dan Keselamatan Kerja, 4(2): 1-10

Noveyani, A.E., Martini, S. 2013. Evaluasi Program Pengendalian Tuberkulosis Paru Dengan Strategi DOTS di Puskesmas Tanah Kali Kedinding. Jurnal Berkala Epidemiologi, 2(2): 251-262

Rintiswati, N., Mahendradhata, Y., Suharna, Susilawati, Purwanta, Subronto, Y., Varkevisser CM, \& Werf, MJ. 2009. Journeys to Tuberculosis Treatment: A Qualitative Study of Patients, Families and Communities in Yogyakarta, Indonesia. BMC Public Health, 9(8): 158-169

Roddawwar, V. 2008. Advocacy, Communication, and Social Mobilisation (ACSM) Tuberculosis Control: an Assessment. The University of Sheffield, 23(44): 18-189

Tondong, M. A., Mahendradhata. Y., \& Ahmad, R.A. 2014. Evaluasi Implementasi Publik Private Mix Pengendalian Tuberkulosis di Kabupaten Ende Provinsi Nusa Tenggara Timur Tahun 2012. Jurnal Kebijakan Kesehatan Indonesia, 3(1): 37-42

Umiasih, S., \& Handayani, O.W. 2018. Peran Serta Kelompok Masyarakat Peduli Paru Sehat dalam Program Pengendalian Penyakit Tuberkulosis. HIGEIA, 2(1): 125-136

WHO. 2009. WHO Policy on TB Infection Control in Health-Care Facilities, Congregate, Setting and Household. Geneva: The World Health Organization

Zignol, M., Dean, A.S., Falzon, D., Gemert, W., Wright, A., Deun, A., Portaels, F., Laszlo, A., Espinal, M.A., Mendez, A., Bloom, A., \& Aziz, M.A. 2016. Twenty Years of Global Surveillance of Anti Tuberculosis-Drug Resistance. The New England Journal of Medicine, 375(11): 1081-1089 